\title{
ANALISIS RESPON PENUMPANG TERHADAP PENERAPAN NEW NORMAL PADA LAYANAN KERETA API JARAK JAUH DI PULAU JAWA
}

\author{
Handoko'1, Email : handoko@ppi.ac.id \\ Erifendi Churniawan², Email : erifendi @ppi.ac.id \\ Fadli Rozaq ${ }^{3}$, Email : fadli@pengajar.ppi.ac.id
}

1),2),3) Manajemen Transportasi Perkeretaapian, Politeknik Perkeretaapian Indonesia Madiun

\begin{abstract}
ABSTRAK
Masuknya wabah virus corona atau pandemi Covid 19 awal tahun 2020 ke negara Indonesia kini telah mengubah tata kehidupan masyarakat. Salah satu sektor yang terkena imbasnya yaitu transportasi kereta api. Meskipun berbagai upaya telah dilakukan pemerintah untuk mengurangi penyebaran virus ini, namun seiring berjalannya waktu ternyata tidak menunjukkan tanda-tanda bahwa virus ini akan segera berakhir, sehingga pemerintah menetapkan adaptasi kebiasaan baru dalam setiap aktivitas masyarakat. Oleh karena itu, PT KAI juga bersiap kembali untuk mengoperasikan kereta api reguler dengan menerapkan protokol pencegahan Covid-19 yang ketat. Penelitian ini bertujuan untuk mengetahui respon penumpang terhadap penerapan new normal pada layanan kereta api jarak jauh di pulau jawa. Penelitian ini merupakan jenis penelitian deskriptif dengan menggunakan pendekatan kuantitatif. Populasi penelitian ini adalah seluruh masyarakat yang mempunyai pengalaman menjadi penumpung kereta api jarak jauh di pulau jawa. teknik sampling yang digunakan adalah teknik sampling insidental dengan jumlah sampel sebanyak 430 responden. Adapun teknik pengumpulan data yang digunakan yaitu kuisioner. Hasil penelitian ditemukan bahwa penumpang menyatakan sangat setuju dengan penerapan new normal pada layanan kereta api jarak jauh yang diterapkan oleh PT KAI.
\end{abstract}

Kata Kunci: Respon Penumpang, New Normal, Kereta Api Jarak Jauh

\section{ABSTRACT}

The entry of the corona virus outbreak or the Covid 19 pandemic in early 2020 into Indonesia has now changed the order of people's lives. One sector that has been affected is rail transportation. Although various efforts have been made by the government to reduce the spread of this virus, over time it has shown no signs that this virus will end soon, so the government has adopted new habitual adaptations in every community activity. Therefore, PT KAI is also preparing to return to operate regular trains by implementing a strict Covid-19 prevention protocol. This study aims to determine the response of passengers to the implementation of the new normal on long-distance train services on the island of Java. This research is a descriptive research using a quantitative approach. The population of this research is all people who have experience as long-distance train passengers on the island of Java. The sampling technique used was incidental sampling technique with a total sample of 430 respondents. The data collection technique used was a questionnaire. The results of the study found that passengers stated that they strongly agreed with the implementation of the new normal in long-distance train services implemented by PT KAI.

Keywords: Passenger Response, New Normal, Long Distance Train

\section{PENDAHULUAN}

Sejak merebaknya virus corona di Indonesia awal tahun 2020 telah membawa dampak yang signifikan pada transportasi kereta api. Jumlah penumpang kereta api mengalami penurunan sebagai akibat dari himbauan pemerintah untuk mengurangi aktivitas di luar rumah. PT KAI juga telah membatasi okupansi atau jumlah penumpang hingga 50\% dari kapasitas yang seharusnya. Tingkat okupansi tersebut disesuaikan dengan Surat Edaran Gugus Tugas Nomor 4 tentang Kriteria Pembatasan Perjalanan 
Orang dalam Rangka Percepatan Penanganan Covid-19 [1].

Berbagai upaya pencegahan telah dilakukan pemerintah untuk mengurangi penyebaran virus Covid-19 ini, diantaranya yaitu membuat kebijakan Pembatasan Sosial Berskala Besar (PSBB) dan membatasi transportasi umum untuk beroperasi. Untuk menindaklanjuti kebijakan tersebut PT Kereta Api Indonesia sebagai operator layanan jasa transportasi kereta api di Indonesia juga membatalkan seluruh perjalanan kereta api jarak jauh dari dan menuju Jakarta dan Bandung mulai bulan April 2020 dan diperpanjang hingga 17 Juni 2020. Untuk itu, calon penumpang yang telah memesan tiket mendapatkan pengembalian bea tiket sebesar $100 \%$ dari harga tiket yang telah dibeli. Adapun pembatalan tiket dapat dilakukan melalui dua cara yaitu melalui KAI Access dan melalui loket. Dengan demikian maka sejak bulan April 2020 PT KAI tidak lagi mengoperasikan kereta api jarak jauh dari Jakarta dan Bandung menuju kotakota di wilayah Jawa Barat, Jawa Tengah, Yogyakarta dan Jawa Timur. Akibat berhentinya kegiatan operasional tersebut PT KAI mengalami kerugian hingga miliaran rupiah [2].

Seiring berjalannya waktu ternyata pandemi Covid19 belum menunjukkan akan segera berakhir, sedangkan perekonomian mulai menurun maka pemerintah menyiapkan skenario adaptasi kehidupan baru (New Normal). Kini kegiatan masyarakat kembali berjalan dengan tatanan kehidupan baru yaitu The New Normal. Menindaklanjuti arahan Menteri BUMN melalui surat nomor S-336/MBU/05/2020 pada 15 Mei 2020 perihal Antisipasi Skenario The New Normal BUMN, PT Kereta Api Indonesia telah menyiapkan protokol untuk mengantisipasi sekenario penerapan New Normal [3]. Protokol tersebut akan mengatur langkah-langkah dan tahapan yang akan diterapkan oleh PT KAI dalam pelayanan kepada pelanggan baik pada bisnis angkutan penumpang maupun barang. New Normal KAI ini sebagai bentuk adaptasi pelayanan perkeretaapian dengan mengurangi kontak fisik dan menerapkan protokol kesehatan.

PT KAI menjelaskan beberapa hal yang diatur dalam pedoman New Normal ini yaitu: pertama, pemesanan tiket hanya dapat dilakukan secara online yaitu Aplikasi KAI Access, Web KAI, dan mitra penjualan tiket resmi KAI lainnya. Sedangkan loket hanya difungsikan untuk pembelian go show (tiga jam sebelum jadwal Keberangkatan) [4].
Kedua, Saat memasuki area stasiun masyarakat diwajibkan untuk memakai masker dan bersuhu tubuh kurang dari 37,3 derajat Celsius. Pada proses boarding, penumpang harus menunjukkan tiket dan identitas kepada petugas boarding. Jika sudah diperiksa, maka penumpang melakukan scan tiket secara mandiri. Ketiga, selama perjalanan, selain menggunakan masker, penumpang juga diharuskan mengenakan face shield yang disediakan oleh KAI. Face Shield tersebut wajib digunakan penumpang hingga keluar dari area stasiun kedatangan. Keempat, guna memastikan kesehatan penumpang, petugas akan mengukur suhu badan penumpang di atas kereta tiap 3 jam sekali. Jika ada penumpang yang kedapatan bersuhu badan 37,3 derajat Celsius atau lebih dan mengalami gejala Covid-19, maka penumpang tersebut akan dipindah ke ruang isolasi yang ada di kereta. Selanjutnya, jika kondisi penumpang perlu penanganan segera, maka petugas akan menghubungi dokter atau petugas kesehatan di stasiun terdekat yang memiliki fasilitas pos kesehatan. Kelima, untuk menjamin kebersihan selama perjalanan, petugas akan rutin membersihkan objek-objek yang sering terpegang tangan setiap 30 menit sekali secara bergantian. Objek tersebut seperti pegangan pintu, pengunci pintu, keran air, tombol flush toilet, sandaran tangan, meja lipat, dan lainnya dibersihkan menggunakan pembersih yang mengandung disinfektan.

Selain itu, petugas frontliner KAI yang berpotensi kontak jarak dekat dengan penumpang dibekali dengan APD berupa masker, sarung tangan, dan face shield dalam melayani pelanggan pada New Normal Petugas tersebut antara lain petugas loket, customer service, petugas boarding, kondektur, Polsuska, pramugari kereta, dan petugas kebersihan di atas kereta. Di samping itu, KAI juga tetap membersihkan kereta dan fasilitas stasiun secara intensif menggunakan bahan pembersih yang mengandung disinfektan. Fasilitas higienitas berupa wastafel portabel dan hand sanitizer juga disediakan di titik-titik yang mudah dijangkau oleh penumpang.

Dalam hal okupansi penumpang PT KAI memiliki dua skenario, pertama yaitu mengikuti pola physical distancing dengan okupansi penumpang 50\% dari total kapasitas kereta. Dengan okupansi tersebut, maka perjalanan satu kereta dipastikan akan rugi, sehingga diperlukan penyesuain tarif. Kedua, yaitu mengikuti kapasitas biasa atau full dengan protokol pencegahan covid-19 yang lebih ketat.

Berdasarkan uraian tentang penerapan New Normal dan skenario okupansi penumpang kereta api di 
atas maka penulis memandang sangat penting untuk dilakukan penelitian tentang respon penumpang terhadap hal tersebut. Hal ini agar pelaksanaan $\mathrm{New}$ Normal pada layanan kereta api dapat berjalan dengan baik dan tidak merugikan pihak-pihak yang berkepentingan. Adapun rumusan masalah pada penelitan ini adalah sebagai berikut:

1. Bagaimana respon penumpang terhadap penerapan New Normal tentang prosedur pemesanan tiket kereta api?

2. Bagaimana respon penumpang terhadap penerapan New Normal tentang prosedur sebelum dan sesudah boarding serta selama perjalanan di kereta api?

3. Bagaiman respon penumpang terhadap penerapan New Normal tentang prosedur penanganan kebersihan dan penyediaan fasilitas kebersihan di stasiun dan di kereta api?

4. Bagaiman respon penumpang terhadap penerapan New Normal tentang persyaratan Surat Bebas Covid-19?

5. Bagaiman respon penumpang terhadap penerapan New Normal tentang skenario okupansi penumpang?

\section{KAJIAN PUSTAKA}

\subsection{Respon Penumpang}

Respon berasal dari kata response, yang berarti tanggapan, aksi, atau jawaban [5]. Hampir sama dengan makna respon yang dikemukakan oleh azwar yaitu suatu reaksi atau jawaban yang bergantung pada stimulus atau merupakan hasil stimulus tersebut [6]. Sedangkan menurut Kartono [7] respon adalah suatu jawaban, khususnya satu jawaban bagi pertanyaan atau satu kuesioner atau seberang tingkah laku, baik yang jelas kelihatan atau lahirilah maupun yang tersembunyi atau tersamar.

Respon adalah setiap tingkah laku pada hakekatnya merupakan tanggapan atau balasan (respon) terhadap rangsangan atau stimulus. Respon adalah suatu reaksi atau jawaban yang bergantung pada stimulus atau merupakan hasil stimulus tersebut. Individu manusia berperan serta sebagai pengendali antara stimulus dan respon sehingga yang menentukan bentuk respon individu terhadap stimulus adalah stimulus dan faktor individu itu sendiri. Oleh karena itu, dengan stimulus yang sama maka setiap individu akan memberikan respon yang berbeda.

Dari uraian di atas maka dapat disimpulkan bahwa respon yang dimaksud dalam penelitian ini yaitu sikap yang muncul setelah adanya stimulus berupa penerimaan melalui pancaindera yang nantinya akan membentuk tingkah laku baru berupa persetujuan atau penolakan. Dengan demikian maka respon penumpang merupakan sikap yang muncul setelah adanya kebijakan baru mengenai penerapan new normal pada layanan kereta api jarak jauh yang berupa persetujuan atau penolakan. Respon seseorang dapat dalam bentuk baik atau buruk, positif atau negatif. Apabila respon positif maka orang yang bersangkutan cenderung untuk menyukai atau mendekati objek, sedangkan respon negatif cenderung untuk menjauhi objek tersebut..

\subsection{Gambaran Umum Layanan Kereta Api Jarak} Jauh di Pulau Jawa Selama Pandemi Covid-19

Covid-19 merupakan penyakit menular yang disebabkan oleh virus jenis coronavirus. Penyakit ini dikenal sejak ditemukannya kasus pertama kali yang ditemukan di Wuhan, Tiongkok, bulan Desember 2019. Penyakit ini kini telah banyak menyebar dan tmenjadi pandemi di berbagai negara di seluruh dunia [8]. Gejala-gejala COVID-19 yang paling umum adalah demam, batuk kering, dan rasa lelah. Gejala lainnya yang lebih jarang dan mungkin dialami beberapa pasien meliputi rasa nyeri dan sakit, hidung tersumbat, sakit kepala, konjungtivitis, sakit tenggorokan, diare, kehilangan indera rasa atau penciuman, ruam pada kulit, atau perubahan warna jari tangan atau kaki. Gejala-gejala yang dialami biasanya bersifat ringan dan muncul secara bertahap. Beberapa orang menjadi terinfeksi tetapi hanya memiliki gejala ringan [9] [10].

COVID-19 dapat menyebar terutama dari orang ke orang melalui percikan-percikan dari hidung atau mulut yang keluar saat orang yang terinfeksi COVID-19 batuk, bersin atau berbicara [11]. Virus juga dapat menyebar secara tidak langsung melalui benda-benda yang tercemar virus akibat percikan atau sentuhan tangan yang tercemar virus. Virus bisa tertinggal di permukaan benda-benda dan hidup selama beberapa jam hingga beberapa hari, namun cairan disinfektan dapat membunuhnya. Jika tangan tercemar percikan, virus dapat menyebar melalui sentuhan antar-orang, karena itu penting untuk sering mencuci tangan pakai sabun dan air mengalir serta sementara waktu, menghindari bersalaman atau saling mencium pipi.

Masuknya wabah virus corona atau pandemi Covid 19 awal tahun 2020 ke negara Indonesia kini telah mengubah tata kehidupan masyarakat. Salah satu sektor yang terkena imbasnya yaitu transportasi kereta api. Berbagai upaya telah dilakukan pemerintah untuk mengurangi penyebaran virus ini, 
diantaranya yaitu himbauan kepada masyarakat untuk tetap tinggal di rumah dan membuat peraturan Pembatasan Sosial Berskala Besar (PSBB).

Kini Indonesia tengah mulai memasuki tata kehidupan baru dengan adaptasi kebiasaan baru. Berbagai sektor kehidupan masyarakat mulai berjalan kembali dengan mengikuti protokol kesehatan dalam rangka pencegahan Covid-19. Demikian juga PT KAI bersiap kembali untuk mengoperasikan Kereta Api jarak jauh. Tanggal 12 Juni 2020 ditetapkan sebagai awal dimulainya pengoperasian kembali kereta api reguler dengan menerapkan protokol pencegahan Covid-19 yang ketat. Pengoperaian kembali KA reguler ini mengacu pada Surat Tugas Percepatan Penanganan Covid-19 Nomor 7 Tahun 2020 tentang Kriteria dan Persyaratan Perjalanan Orang dalam Masa Adaptasi Kebiasaan Baru Menuju Masyarakat Produktif dan Aman Covid-19 dan surat edaran ditjenka kemenhub Nomor 14 tahun 2020 tanggal 8 juni 2020 tentang pedoman dan petunjuk Teknis Pengendalian Transportasi Perkertaapian dalam Masa Adaptasi Kebiasaan Baru untuk Mencegah Penyebaran Covid-19 [12], [13].

Pengoperasian KA reguler tersebut tidak langsung dibuka untuk seluruh rute perjalanan kereta, namun dilakukan secara bertahap yang akan dievaluasi kembali pelaksanaannya melihat kondisi dilapangan.

\subsection{Penerapan New Normal pada Layanan Kereta} Api Jarak Jauh

Pedoman New Normal KAI disusun mengacu pada Keputusan Menteri Kesehatan Nomor HK.01.07/Menkes/328/2020 tentang Panduan Pencegahan dan Pengendalian Covid-19 di Tempat Kerja Perkantoran dan Industri dalam Mendukung Keberlangsungan Usaha pada Situasi Pandemi [14]. Adapun pada penelitian ini pedoman New Normal KAI dibagi menjadi 5 kategori yaitu sebagai berikut:

1. Prosedur pemesanan tiket kereta api

Pemesanan tiket hanya dapat dilakukan secara online yaitu Aplikasi KAI Access, Web KAI, dan mitra penjualan tiket resmi KAI lainnya. Sedangkan loket hanya difungsikan untuk pembelian go show (tiga jam sebelum jadwal Keberangkatan).

2. Prosedur sebelum dan sesudah boarding serta selama perjalanan di kereta api.

a. Saat memasuki area stasiun masyarakat diwajibkan untuk memakai masker dan bersuhu tubuh kurang dari 37,3 derajat Celsius.

b. Pada proses boarding, penumpang harus menunjukkan tiket dan identitas kepada petugas boarding. Jika sudah diperiksa, maka penumpang melakukan scan tiket secara mandiri.

c. Selama perjalanan, selain menggunakan masker, penumpang juga diharuskan mengenakan face shield yang disediakan oleh KAI. Sedangkan untuk penumpang dibawah 3 tahun maka diwajibkan untuk menyediakan face shield sendiri. Face Shield tersebut wajib digunakan penumpang hingga keluar dari area stasiun kedatangan.

d. Untuk memastikan kesehatan penumpang, petugas akan mengukur suhu badan penumpang di atas kereta tiap 3 jam sekali. Jika ada penumpang yang kedapatan bersuhu badan 37,3 derajat Celsius atau lebih dan mengalami gejala Covid-19, maka penumpang tersebut akan dipindah ke ruang isolasi yang ada di kereta. Selanjutnya, jika kondisi penumpang perlu penanganan segera, maka petugas akan menghubungi dokter atau petugas kesehatan di stasiun terdekat yang memiliki fasilitas pos kesehatan.

3. Prosedur penanganan kebersihan dan penyediaan fasilitas kebersihan di stasiun dan di kereta api.

a. KAI membersihkan kereta dan fasilitas stasiun secara intensif menggunakan bahan pembersih yang mengandung disinfektan.

b. KAI menyediakan fasilitas higienitas berupa wastafel portabel dan hand sanitizer di titiktitik yang mudah dijangkau oleh penumpang

c. Untuk menjamin kebersihan selama perjalanan di kereta api, KAI akan rutin membersihkan objek-objek yang sering terpegang tangan setiap 30 menit sekali secara bergantian. Objek tersebut seperti pegangan pintu, pengunci pintu, keran air, tombol flush toilet, sandaran tangan, meja lipat, dan lainnya dibersihkan menggunakan pembersih yang mengandung disinfektan.

4. Persyaratan Surat Bebas Covid-19

Pelanggan KA Jarak Jauh diharuskan melengkapi persyaratan sesuai Surat Edaran Gugus Tugas Covid-19 No 9 Tahun 2020. Berkas-berkas tersebut harus ditunjukkan kepada petugas pada saat melakukan boarding. Adapun ketentuannya yaitu:

a. Menunjukkan surat keterangan uji tes PCR dengan hasil negatif atau surat keterangan uji Rapid-Test dengan hasil non reaktif yang 
berlaku 14 hari sejak diterbitkan pada saat keberangkatan

b. Menunjukkan surat keterangan bebas gejala seperti influenza (influenza-like illness) yang dikeluarkan oleh dokter rumah sakit/puskesmas bagi daerah yang tidak memiliki fasilitas test PCR dan/atau Rapid Test.

c. Mengunduh dan mengaktifkan aplikasi Peduli Lindungi pada perangkat seluler.

5. Skenario okupansi penumpang

Dalam hal okupansi penumpang PT KAI memiliki dua skenario, pertama yaitu mengikuti pola physical distancing dengan okupansi penumpang $50 \%$ dari total kapasitas kereta. Dengan okupansi tersebut, maka perjalanan satu kereta dipastikan akan rugi, sehingga diperlukan penyesuain tarif. Kedua, yaitu mengikuti kapasitas biasa atau full dengan protokol pencegahan covid-19 yang lebih ketat.

\section{METODE}

Penelitian ini merupakan jenis penelitian deskriptif dengan menggunakan pendekatan kuantitatif. Populasi dalam penelitian ini adalah seluruh masyarakat yang mempunyai pengalaman menjadi penumpung kereta api jarak jauh di pulau jawa. Dalam menentukan sampel, teknik yang digunakan adalah teknik sampling insidental. Pengambilan sampel penelitian ini berdasarkan kriteria yaitu: masyarakat yang mempunyai pengalaman menjadi penumpung kereta api jarak jauh di pulau jawa dan jumlah sampel yang digunakan yaitu 430 responden.

Data yang dikumpulkan pada penelitian ini yaitu berupa data primer. Adapun teknik pengumpulan data yang digunakan yaitu kuisioner. Instrumen penenelitian disusun dengan mengacu pada pedoman New Normal KAI yang telah dirilis pada website resmi $\quad$ PT $\quad$ KAI (https://kai.id/information/full_news). Jenis kuisioner yang digunakan yaitu kuisinoner tertutup dengan empat alternatif jawaban, yaitu skor 4 (sangat setuju), skor 3 (setuju), skor 2 (tidak setuju), skor 1 (sangat tidak setuju) atas penerapan New Normal pada layanan kereta api jarak jauh di pulau jawa.

Kuesioner yang dikembangkan terdiri dari 20 butir pernyataan yang selanjutnya diujicoba untuk di analisis validitas dan reliabilitasnya. Uji validitas instrumen penelitian ini menggunakan teknik korelasi bivariate antara masing-masing skor butir pernyataan dengan total skor konstruk. Nilai korelasi bivariate diperoleh dengan menggunakan bantuan program SPSS for windows release 16.00. Untuk mengetahui apakah instrumen yang digunakan valid atau tidak, maka dilihat dari nilai sig dengan taraf signifikansi $5 \%$ atau 0,05 pada tabel corellation. Apabila nilai sig $\geq 0,05$ maka butir pernyataan pada instrumen peneltiain dikatakan valid, dan apabila nilai sig $\leq 0,05$ maka instrumen dikatakan tidak valid. Selanjutnya untuk uji reliabilitas instrumen penelitian ini menggunakan teknik uji statistik Cronbach Alpha $(\dot{a})$. Suatu variabel dikatakan reliabel jika memberikan nilai Cronbach Alpha > 0,60. Nilai Cronbach Alpha diperoleh dengan menggunakan bantuan program SPSS for windows release 16.00.

Uji coba instrumen dilakukan dengan menggunakan 100 responden. Berdasarkan hasil uji validitas instrumen diketahui bahwa dari 20 butir pernyataan tentang respon penumpang terhadap penerapan New Normal pada layanan kereta api jarak jauh di pulau jawa semua butir pernyataan dalam kategori valid. Selanjutnya hasil uji reliabilitas instrumen diketahui bahwa nilai Cronbach's Alpha instrumen penelitian yaitu 0,925 lebih besar dari 0,60 sehingga instrumen tersebut dikatakan reliabel. Dengan demikian maka 20 butir pernyataan dinyatakan valid dan reliabel sehingga digunakan sebagai alat pengambil data penelitian.

Analsis data pada penelitian ini menggunakan analisis deskriptif. Analisis deskriptif merupakan tekhnik analisis yang dipakai untuk menganalisis data dengan mendeskripsikan atau menggambarkan data-data yang sudah dikumpulkan seadanya tanpa ada maksud membuat generalisasi dari hasil penelitian. Analisis deskriptif digunakan untuk mendeskripsikan data-data mengenai respon penumpang terhadap penerapan New Normal pada layanan kereta api jarak jauh di pulau jawa, dan tanggapan penumpang terhadap urgensi penerapan New Normal pada layanan kereta api jarak jauh di pulau jawa.

\section{HASIL DAN PEMBAHASAN}

\subsection{Karakteristik Responden}

Karakteristik responden dalam penelitian ini dideskripsikan berdasarkan 6 kategori, yaitu berdasarkan jenis kelamin, umur, pekerjaan, pendidikan, tujuan perjalanan, rata-rata penghasilan perbulan, dan frekuensi naik kereta jarak jauh dalam satu bulan. Jumlah responden yang mengisi kuisioner penelitian yaitu sebanyak 430 responden. Deskripsi secara lebih 
lengkap karakteristik responden adalah sebagai berikut:

1. Berdasarkan jenis kelamin

Karakteristik ressponden berdasarkan jenis kelamin pada penelitian ini dibagi menjadi 2 (dua) kategori yaitu laki-laki dan perempuan. Berikut data responden berdasarkan jenis kelamin:

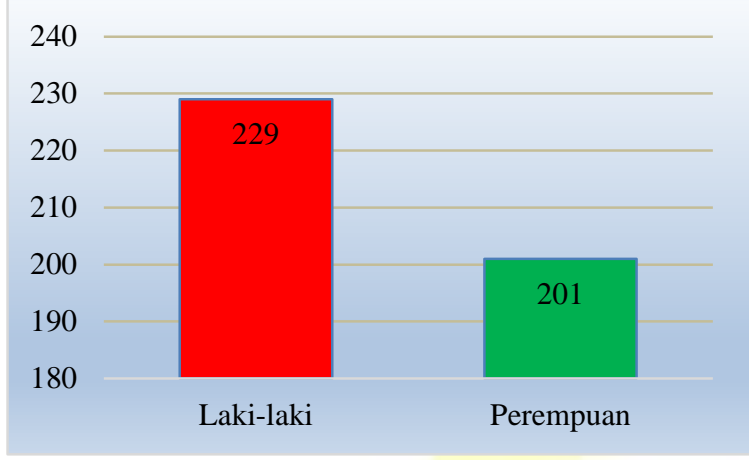

(a)

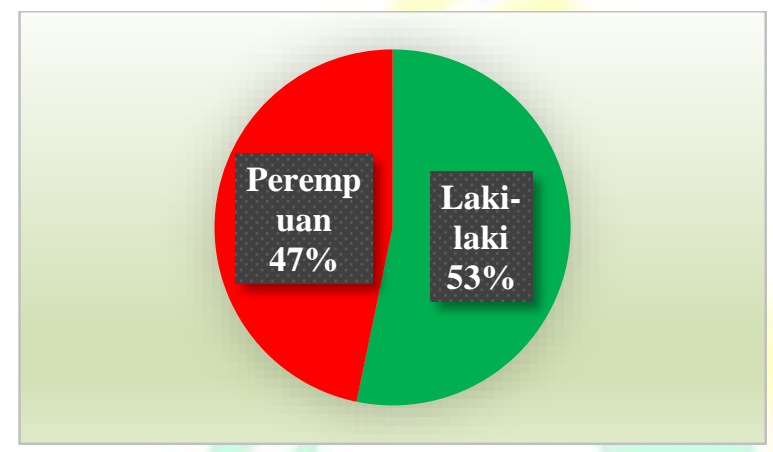

(b)

Gambar 1. Berdasarkan Jenis Kelamin

Berdasarkan Gambar 4.1 di atas dapat diketahui bahwa responden berjenis kelamin laki-laki memiliki persentasi lebih banyak yaitu sebesar 53\%. Oleh karena itu, dapat disimpulkan bahwa responden pada penelitian ini didominasi oleh penumpang berjenis kelamin laki-laki.

2. Berdasarkan umur

Karakteristik responden berdasarkan umur pada penelitian ini dibagi menjadi 4 (empat) kategori yaitu $<20$ tahun, 21-30 tahun, 31-40 tahun, dan $>41$ tahun. Berikut data responden berdasarkan jenis umur:

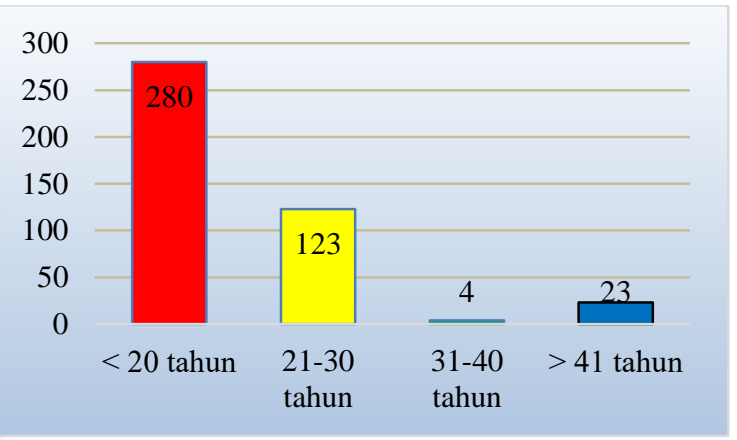

(a)

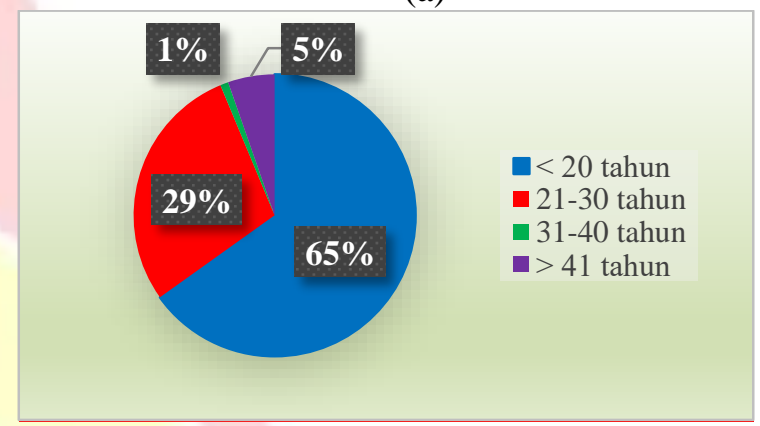

(b)

Gambar 2. Berdasarkan Umur

Berdasarkan Gambar 2 di atas dapat diketahui bahwa responden terbanyak ada di rentang umur $<20$ tahun yaitu sebesar $65 \%$. Oleh karena itu, dapat disimpulkan bahwa responden pada penelitian ini didominasi oleh penumpang usia muda. Hal ini disebabkan karena kuisioner yang dibagikan yaitu berupa kuisioner online berupa Google Form, sehingga kalangan yang familiar dengan internet lebih banyak dari usia muda.

3. Berdasarkan pekerjaan

Karakteristik ressponden berdasarkan pekerjaan pada penelitian ini dibagi menjadi 5 (lima) kategori yaitu ASN/TNI/POLRI, wirausaha, pelajar/mahasiswa, karyawan swasta, dan lainnya. Berikut data responden berdasarkan pekerjaan:

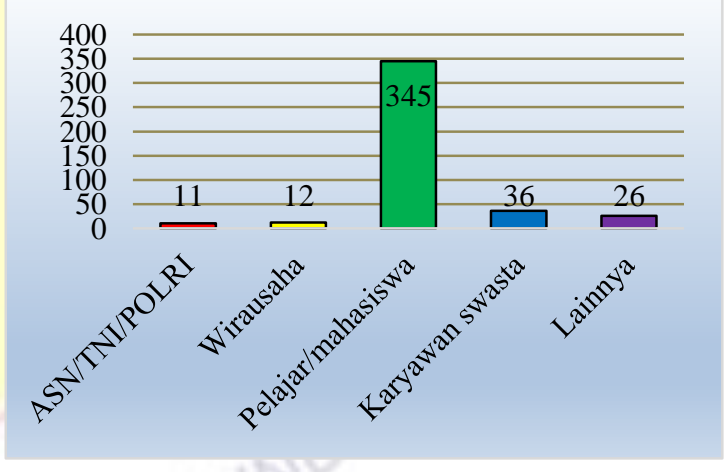

(a) 


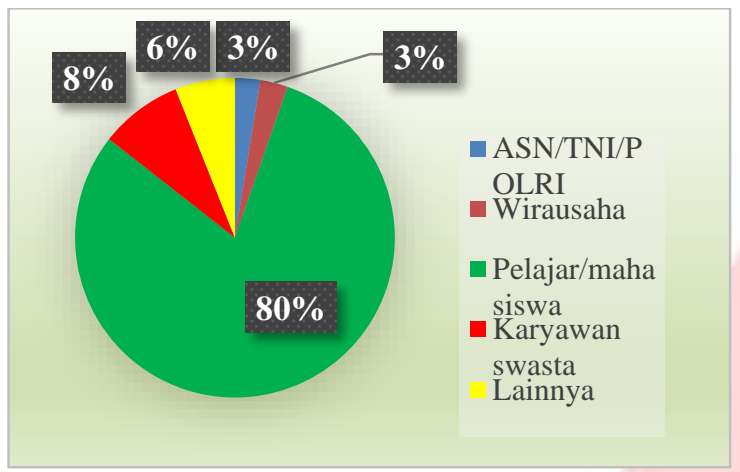

(b)

Gambar 3. Berdasarkan Pekerjaan

Berdasarkan Gambar 4.3 di atas dapat diketahui bahwa responden terbanyak berada pada kelompok jenis pekerjaan pelajar/mahaiswa yaitu sebesar $80 \%$. Hal ini sesuai dengan rentang usia terbanyak responden yaitu pada usia $<20$ tahun dimana pada usia tersebut merupakan usia pelajar/mahasiswa. Oleh karena itu, dapat disimpulkan bahwa responden pada penelitian ini didominasi oleh penumpang dengan jenis pekerjaan pelajar/mahasiswa.

4. Berdasarkan pendidikan

Karakteristik ressponden berdasarkan pendidikan pada penelitian ini dibagi menjadi 5 (lima) kategori yaitu SD-SMP, SMA/Sederajat, Diploma, Sarjana/S1, dan S2/S3. Berikut data responden berdasarkan pendidikan:

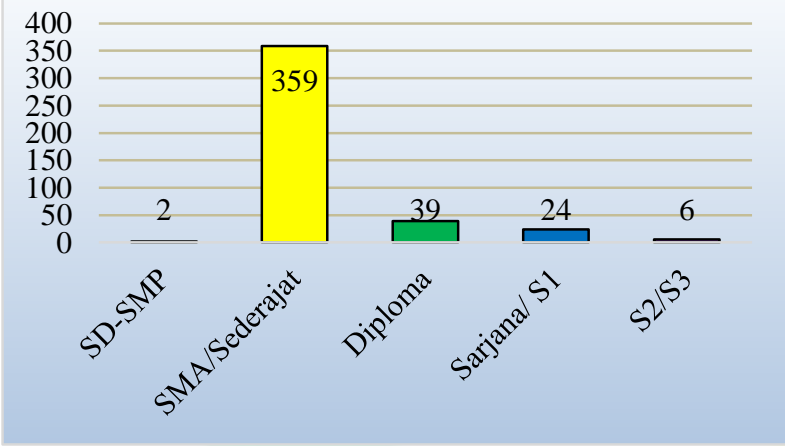

(a)

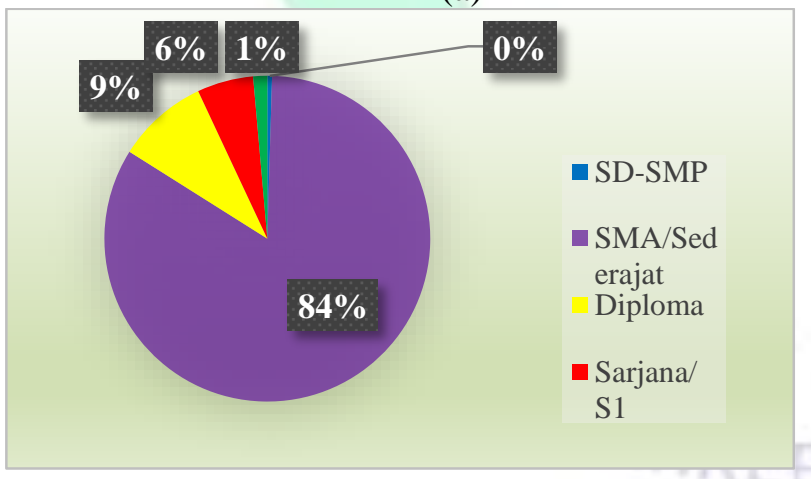

(b)

Gambar 4. Berdasarkan pendidikan
Berdasarkan Gambar 4.4 di atas dapat diketahui bahwa responden terbanyak ada dikelompok lulusan SMA/Sederajat yaitu sebesar 84\%. Oleh karena itu, dapat disimpulkan bahwa responden pada penelitian ini didominasi oleh penumpang dengan pendidikan terakhir lulusan SMA/Sederajat.

5. Berdasarkan tujuan perjalanan

Karakteristik ressponden berdasarkan tujuan perjalanan pada penelitian ini dibagi menjadi 4 (empat) kategori yaitu pekerjaan/bisnis, studi, wisata, dan lainnya. Berikut data responden berdasarkan tujuan perjalanan:

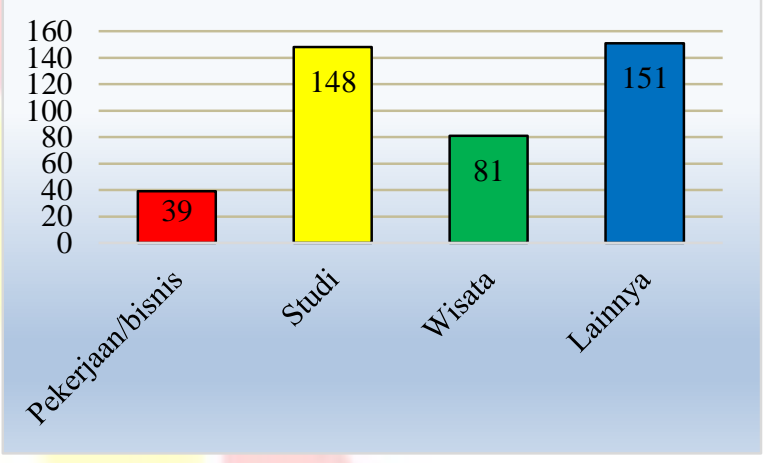

(a)

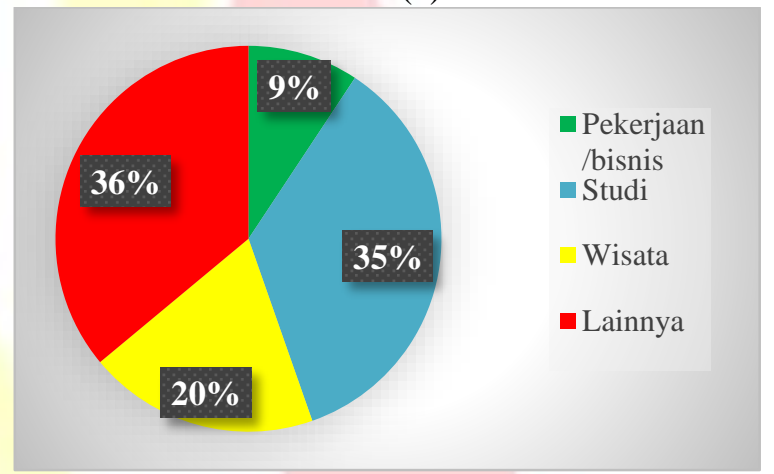

(b)

Gambar 5. Berdasarkan Tujuan Perjalanan

Berdasarkan Gambar 4.5 di atas dapat diketahui bahwa ada 2 kelompok tujuan perjalanan yang persentasenya hampir sama yaitu tujuan lainnya dan tujuan studi, masing-masing sebesar $36 \%$ dan $35 \%$. Jika dikaitkan dengan jenis pekerjaan responden maka hal akan selaras yaitu responden terbanyak merupakan pelajar/mahasiswa. Oleh karena itu, dapat disimpulkan bahwa responden pada penelitian ini didominasi oleh penumpang dengan tujuan perjalanan untuk studi dan tujuan lainnya. 
4.2 Respon Penumpang terhadap Penerapan New Normal pada Layanan Kereta Api Jarak Jauh di Pulau Jawa

Analisis deskriptif pada penelitian ini digunakan untuk mendeskripsikan data mengenai respon penumpang terhadap penerapan New Normal pada layanan kereta api jarak jauh di pulau jawa yang dibagi menjadi 5 indikator yaitu: (a) prosedur pemesanan tiket kereta api; (b) prosedur sebelum dan sesudah boarding serta selama perjalanan di kereta api; (c) prosedur penanganan kebersihan dan penyediaan fasilitas kebersihan di stasiun dan di kereta api, (d) persyaratan Surat Bebas Covid-19, dan (e) skenario okupansi penumpang. Analisis deskriptif persentase masing-masing indikator diperoleh hasil sebagai berikut:

\section{Prosedur pemesanan tiket kereta api}

Indikator prosedur pemesanan tiket kereta api merupakan ketentuan dalam melakukan pemesanan/ reservasi tiket kereta api. Sebelum masa pandemi Covid-19 pemesanan tiket kereta api dapat dilakukan secara online melalui aplikasi maupun offline (diloket stasiun kereta api), akan tetapi dalam masa new normal atau adaptasi kebiasaan baru ini tiket hanya bisa dipesan secara online dan loket hanya digunakan untuk pemesanan tiket go show. Ada 3 pernyataan yang mewakili indikator prosedur pemesanan tiket kereta api dengan hasil sebagai berikut:

Tabel 1. Prosedur pemesanan tiket kereta api

\begin{tabular}{|c|c|c|c|c|}
\hline Pernyataan & STS & $\mathrm{TS}$ & S & SS \\
\hline $\begin{array}{l}\text { 1. Pemesanan tiket } \\
\text { secara online } \\
\text { melalui Aplikasi } \\
\text { KAI Access, Web } \\
\text { KAI, dan mitra } \\
\text { penjualan tiket } \\
\text { resmi KAI } \\
\text { lainnya }\end{array}$ & 0 & 8 & 135 & 286 \\
\hline $\begin{array}{l}\text { 2. Penggunaan tiket } \\
\text { elektronik }\end{array}$ & 2 & 7 & 143 & 278 \\
\hline $\begin{array}{l}\text { 3. Loket hanya } \\
\text { difungsikan untuk } \\
\text { pembelian tiket go } \\
\text { show }\end{array}$ & 0 & 1 & 126 & 301 \\
\hline
\end{tabular}

Berdasarkan Tabel 1 diketahui pada indikator prosedur pemesanan tiket kereta api dari 3 butir pernyataan yang mewakili nilai tertingginya semua terdapat pada kategori sangat setuju. Pada butir pernyataan 1 nilai terendah pada kategori tidak setuju dengan jumlah responden yaitu 8 orang atau 1,9\%. Pada butir pernyataan 2 nilai terendahnya berada pada kategori sangat tidak setuju dengan jumlah responden 2 atau $0,5 \%$. Pada butir pernyataan 3 nilai terendahnya berada pada kategori tidak setuju dengan jumlah responden 1 atau $0,2 \%$. Dengan demikian maka dapat disimpulkan bahwa penumpang menyatakan sangat setuju dengan prosedur pemesanan tiket kereta api yang ditetapkan oleh KAI.

Pada indikator ini penumpang memberikan masukan bahwa untuk tiket sebaiknya menggunakan tiket elektronik untuk meminimalisir kontak dengan mesin cetak tiket. Tiket ini diharapkan dapat di unduh di smartphone penumpang dan digunakan untuk boarding.

2. Prosedur sebelum dan sesudah boarding serta selama perjalanan di kereta api

Indikator prosedur sebelum dan sesudah boarding serta selama perjalanan di kereta api merupakan ketentuan yang harus ditaati oleh penumpang yang akan melakukan perjalanan dengan menggunakan kereta api mulai dari masuk stasiun hingga keluar dari stasiun kereta api. Ada 8 pernyataan yang mewakili indikator ini dengan hasil sebagai berikut:

Tabel 2. Prosedur sebelum dan sesudah boarding serta selama perjalanan di kereta api

\begin{tabular}{|c|c|c|c|c|}
\hline Pernyataan & STS & TS & S & SS \\
\hline $\begin{array}{l}\text { 1. Wajib menggunakan } \\
\text { masker saat memasuki area } \\
\text { stasiun dan kereta }\end{array}$ & 0 & 0 & 79 & 351 \\
\hline $\begin{array}{l}\text { 2. Pemeriksaan suhu tubuh } \\
\text { sebelum memasuki area } \\
\text { stasiun }\end{array}$ & 0 & 8 & 89 & 332 \\
\hline $\begin{array}{l}\text { 3.Penumpang melakukan } \\
\text { boarding secara mandiri } \\
\text { dengan menunjukkan tiket } \\
\text { dan identitas disaksikan } \\
\text { oleh petugas }\end{array}$ & 4 & 18 & 149 & 259 \\
\hline 4. Wajib menggunakan Face & & & & \\
\hline $\begin{array}{l}\text { Shield selama perjalanan di } \\
\text { kereta }\end{array}$ & 0 & 13 & 161 & 225 \\
\hline $\begin{array}{l}\text { 5.Pembatasan jumlah orang } \\
\text { di stasiun }\end{array}$ & 0 & 4 & 134 & 290 \\
\hline $\begin{array}{l}\text { 6.Pengaturan jarak antrian } \\
\text { memasuki area stasiun, } \\
\text { loket tiket, jalur boarding, } \\
\text { dan pintu masuk kereta }\end{array}$ & 2 & 2 & 133 & 293 \\
\hline $\begin{array}{l}\text { 7.Pengaturan jarak tempat } \\
\text { duduk di ruang tunggu }\end{array}$ & 10 & 95 & 188 & 137 \\
\hline $\begin{array}{l}\text { 8. Pemeriksaan suhu tubuh } \\
\text { setiap } 3 \text { jam sekali selama } \\
\text { perjalanan di kereta }\end{array}$ & 9 & 99 & 179 & 143 \\
\hline
\end{tabular}


Berdasarkan Tabel 2 diketahui bahwa pada indikator prosedur sebelum dan sesudah boarding serta selama perjalanan di kereta api dari 8 butir pernyataan yang mewakili terdapat 6 butir pernyataan yang nilai tertingginya berada pada kategori sangat setuju dan sisanya berada pada kategori setuju. Pada butir pernyataan 1 nilai terendah pada kategori setuju dengan jumlah responden yaitu 79 orang atau $18,4 \%$. Pada butir pernyataan 2, 4 dan 5 nilai terendahnya berada pada kategori tidak setuju dengan jumlah responden masing-masing 8 $(1,9 \%), 13(3 \%)$, dan $4(0,9 \%)$. Pada butir pernyataan $3,6,7$, dan 8 nilai terendahnya berada pada kategori sangat tidak setuju dengan jumlah responden masing-masing $4(0,9 \%), 2$ $(0,5), 10(2,3 \%)$, dan $9(2,1 \%)$. Dengan demikian maka dapat disimpulkan bahwa penumpang menyatakan sangat setuju dengan prosedur sebelum dan sesudah boarding serta selama perjalanan di kereta api yang ditetapkan oleh KA.

Indikator ini merupakan tahap paling krusial dalam kegiatan perjalanan dengan menggunakan kereta api. Masukan diberikan oleh penumpang yaitu agar KAI dapat menerapkan prosedurprosedur yang ditetapkan dengan ketat dan tegas agar penyebaran virus Covid-19 di area stasiun dan kereta.

3. Prosedur penanganan kebersihan dan penyediaan fasilitas kebersihan di stasiun dan di kereta api

Indikator prosedur penanganan kebersihan dan penyediaan fasilitas kebersihan di stasiun dan di kereta api merupakan upaya-upaya yang dilakukan oleh KAI dalam menjaga kebersihan dan menyediakan fasilitas kebersihan di stasiun dan di kereta api untuk mencegah penularan virus Covid-19. Ada 4 pernyataan yang mewakili indikator ini dengan hasil sebagai berikut:

Tabel 3. Prosedur Penanganan Kebersihan

\begin{tabular}{|c|c|c|c|c|}
\hline Pernyataan & STS & TS & S & SS \\
\hline $\begin{array}{l}\text { 1. Pembersihan kereta dan } \\
\text { fasilitas stasiun secara } \\
\text { intensif }\end{array}$ & 0 & 0 & 103 & 326 \\
\hline $\begin{array}{l}\text { 2. Penyediaan wastafel } \\
\text { portable }\end{array}$ & 0 & 3 & 111 & 316 \\
\hline 3. Penyediaan hand sanitizer & 0 & 1 & 01 & 340 \\
\hline $\begin{array}{l}\text { 4. Pembersihan objek-objek } \\
\text { yang sering terpegang } \\
\text { tangan selama perjalanan } \\
\text { di kereta api }\end{array}$ & 0 & 19 & 154 & 257 \\
\hline
\end{tabular}

Berdasarkan Tabel 3 diketahui bahwa pada indikator prosedur penanganan kebersihan dan penyediaan fasilitas kebersihan di stasiun dan di kereta api dari 4 butir pernyataan yang mewakili semua butir pernyataan nilai tertingginya berada pada kategori sangat setuju. Pada butir pernyataan 1 nilai terendah pada kategori setuju dengan jumlah responden yaitu 103 orang atau 24\%. Pada butir pernyataan 2, 3 dan 4 nilai terendahnya berada pada kategori tidak setuju dengan jumlah responden masing-masing 3 $(0,7 \%), 1(0,2 \%)$, dan 19 (4,4\%). Dengan demikian maka dapat disimpulkan bahwa penumpang menyatakan sangat setuju dengan prosedur penanganan kebersihan dan penyediaan fasilitas kebersihan di stasiun dan di kereta api yang ditetapkan oleh KAI.

Pada indikator ini masukan yang diberikan oleh penumpang yaitu supaya prosedur kebersihan dapat dilaksanakan dengan intensif serta selalu memberikan himbauan kepada penumpang untuk menjaga kerbersihan (cuci tangan/memakai hand sanitizer) baik menggunakan gambar maupun suara.

4. Persyaratan Surat Bebas Covid-19 Indikator persyaratan surat bebas Covid-19 merupakan dokumen yang harus disiapkan dan dibawa penumpang apabila akan melakukan perjalanan dengan menggunakan kereta api jarak jauh. Ada 3 pernyataan yang mewakili indikator ini dengan hasil sebagai berikut:

Tabel 4. Persyaratan Surat Bebas Covid-19

\begin{tabular}{lcccc}
\hline Pernyataan & STS & TS & S & SS \\
\hline $\begin{array}{l}\text { 1. Surat keterangan uji tes } \\
\begin{array}{l}\text { PCR atau Rapid-Test } \\
\text { 2urat keterangan sehat } \\
\text { dari dokter rumah sakit/ }\end{array}\end{array}$ & 7 & 35 & 184 & 206 \\
puskesmas & 64 & 181 & 178 \\
$\begin{array}{l}\text { 3. Mengunduh dan } \\
\text { mengaktifkan aplikasi }\end{array}$ & 2 & 4 & 148 & 276 \\
Peduli Lindungi & & & & \\
\hline
\end{tabular}

Berdasarkan Tabel 4 diketahui bahwa pada indikator persyaratan surat bebas Covid-19 dari 3 butir pernyataan yang mewakili terdapat 2 butir pernyataan nilai tertingginya berada pada kategori sangat setuju dan sisanya berada pada kategori setuju. Pada 3 butir pernyataan yang digunakan semuanya mempunyai nilai terendah pada kategori sangat tidak setuju dengan jumlah responden masing-masing yaitu $5(1,2 \%), 7$ $(1,6 \%)$, dan $2(0,5 \%)$. Dengan demikian maka dapat disimpulkan bahwa penumpang 
menyatakan sangat setuju dengan persyaratan surat bebas Covid-19 yang ditetapkan oleh KAI.

Pada indikator ini masukan yang diberikan oleh penumpang yaitu agar persyaratan surat ini tetap diterapkan selama pandemi Covid-19 ini masih berlangsung meskipun sudah memasuki masa New Normal. Hal tersebut sebagai upaya untuk meningkatkan kepercayaan penumpang terhadap keamanan lingkungan stasiun dan kereta api dari penyebaran virus Covid-19.

5. Skenario okupansi penumpang

Indikator skenario okupansi penumpang merupakan rekayasa jumlah penumpang kereta api jarak jauh yang dibuat oleh KAI sebagai upaya pencegahan penyebaran virus Covid-19 di kereta api. Ada 4 pernyataan yang mewakili indikator ini dengan hasil sebagai berikut:

Tabel 4. Skenario Okupansi Penumpang

\begin{tabular}{|c|c|c|c|c|}
\hline Pernyataan & STS & TS & $\mathrm{S}$ & SS \\
\hline $\begin{array}{l}\text { 1. Mengurangi } \\
\text { jumlah penumpang } \\
\text { dengan menaikkan }\end{array}$ & 15 & 71 & 161 & 183 \\
\hline $\begin{array}{l}\text { harga tiket } \\
\text { 2. Jumlah penumpang } \\
\text { tetap dengan } \\
\text { menerapkan }\end{array}$ & & & & \\
\hline $\begin{array}{l}\text { protokol } \\
\text { pencegahan covid- } \\
19 \text { yang lebih } \\
\text { ketat }\end{array}$ & 25 & 106 & 154 & 145 \\
\hline
\end{tabular}

Berdasarkan Tabel 4.5 diketahui bahwa pada indikator skenario okupansi penumpang dari 2 butir pernyataan yang mewakili terdapat 1 butir pernyataan nilai tertingginya berada pada kategori sangat setuju dan sisanya berada pada kategori setuju. Dari 2 alternatif skenario okupansi penumpang dapat diketahui bahwa penumpang cenderung memilih alternatif yang pertama yaitu mengurangi jumlah penumpang dengan menaikkan harga tiket. Hal ini dapat dilihat dari skor masing-masing pilihan jawaban dimana pilihan jawaban tertinggi butir pernyataan 1 berada pada kategori sangat setuju, sedangkan butir pernyataan 2 skor tertinggi berada pada kategori setuju. Selanjutnya pada kategori tidak setuju dan kategori sangat tidak setuju butir pernyataan 1 skornya lebih rendah dari skor yang diperoleh butir pernyataan 2 . Dengan demikian maka dapat disimpulkan bahwa penumpang cenderung memilih alternatif okupansi penumpang mengurangi jumlah penumpang dengan menaikkan harga tiket.

\section{KESIMPULAN}

Berdasarkan hasil penelitian dan pembahasan maka dapat diambil kesimpulan sebagai berikut:

1. Penumpang menyatakan sangat setuju dengan prosedur pemesanan tiket kereta api yang ditetapkan oleh KAI.

2. Penumpang menyatakan sangat setuju dengan prosedur sebelum dan sesudah boarding serta selama perjalanan di kereta api yang ditetapkan oleh KAI.

3. Penumpang menyatakan sangat setuju dengan prosedur penanganan kebersihan dan penyediaan fasilitas kebersihan di stasiun dan di kereta api yang ditetapkan oleh KAI.

4. Penumpang menyatakan sangat setuju dengan persyaratan surat bebas Covid-19 yang ditetapkan oleh KAI.

5. Penumpang cenderung memilih alternatif okupansi penumpang mengurangi jumlah penumpang dengan menaikkan harga tiket.

\section{UCAPAN TERIMA KASIH}

Penulis mengucapkan terimakasih kepada Direktur Politeknik Perkeretaapian Indonesia Madiun dan Pusat Penelitian dan Pengabdian Masyarakat yang telah membiayai dan memfasilitasi dalam pengambilan data penelitian ini

\section{REFERENSI}

[1] Gugus Tugas Percepatan Penanganan Covid19. 2020. Surat Edaran Gugus Tugas Nomor 4 tentang Kriteria Pembatasan Perjalanan Orang dalam Rangka Percepatan Penanganan Covid19.

[2] Public Relations KAI. 2020. Mulai 12 Juni, KAI Kembali Layani Masyarakat dengan KA Reguler $\quad 10 \quad$ Juni 2020 https://kai.id/information/full_news/3556

[3] Menteri BUMN. 2020. Surat Nomor S336/MBU/05/2020 pada 15 Mei 2020 perihal Antisipasi Skenario The New Normal BUMN

[4] Public Relations KAI. 2020. KAI Terapkan Adaptasi Kebiasaan Baru di Perjalanan KA Reguler $11 \quad$ Juni 2020. https://kai.id/information/full_news/3562

[5] Departemen Pendidikan Indonesia. 2008. Kamus Besar Bahasa Indonesia. Jakarta: Balai Pustaka 
[6] Azwar, Saifuddin. (2015). Sikap Manusia: Teori \& Pengukurannya. Yogyakarta: Pustaka Pelajar

[7] J.P Chaplin. 1997. Kamus Lengkap Psikoloy. Judul Asli: Dictionary of Psikology, Diterjemahkan oleh Kartini Kartono, hal. 431. Jakarta: PT. Raja Grafindo Persada

[8] WHO. 2020. Pertanyaan dan jawaban terkait Coronavirus https://www.who.int/indonesia/news/novelcoronavirus/qa-for-public. Di akses tanggal 15 April 2020

[9] International Union of Railways. 2020. Potential measures to restore confidence in rail travel following the Covid-19 pandemic. Maret 2020 .

[10] International Union of Railways. 2020. Management of Covid-19 Guidance For Railway Stakeholders. Maret 2020.

[11] Gugus Tugas Percepatan Penanganan Covid19. 2020. Tanya Jawab. https://covid19.go.id/tanya-jawab?page=4. Di akses tanggal 15 April 2020

[12] Gugus Tugas Percepatan Penanganan Covid19. 2020. Surat Tugas Percepatan Penanganan Covid-19 Nomor 7 Tahun 2020 tentang Kriteria dan Persyaratan Perjalanan Orang dalam Masa Adaptasi Kebiasaan Baru Menuju Masyarakat Produktif dan Aman Covid-19

[13] Menteri Perhubungan. surat edaran Nomor 14 tahun 2020 tanggal 8 juni 2020 tentang pedoman dan petunjuk Teknis Pengendalian Transportasi Perkertaapian dalam Masa Adaptasi Kebiasaan Baru untuk Mencegah Penyebaran Covid-19

[14] Menteri Kesehatan. 2020. Keputusan Menteri Kesehatan Nomor HK.01.07/Menkes/328/2020 tentang Panduan Pencegahan dan Pengendalian Covid-19 di Tempat Kerja Perkantoran dan Industri dalam Mendukung Keberlangsungan Usaha pada Situasi Pandemi. 